\title{
Comparison of the accuracy of implant digital impression coping
}

\author{
Gyo-Zin Ahn, Joon-Seok Lee* \\ Department of Prosthodontics, College of Dentistry, Dankook University, Cheonan, Republic of Korea
}

Purpose: The purpose of this study was to compare the accuracy of impression taking method using the encoded healing abutment, scan body and pick-up impression coping with different implant angulations. Materials and Methods: Master model was fabricated by $3 \mathrm{D}$ printer and three implants were placed into the model with $0^{\circ}, 10^{\circ}$ and $20^{\circ}$ mesial angulation. The abutments were secured to each implants and master model was scanned to make a reference model. Group P model was fabricated using pick-up impression copings and model was scanned after securing the abutments. Encoded healing abutment (Group E) and scan body (Group S) were secured on the master model and digital impression was taken using intraoral scanner 15 times each. Each STL files of test groups were superimposed with reference model using best fit alignment and root mean square (RMS) value was analyzed. Results: The RMS values were lowest in Group P, followed by Group S and Group E. Group P showed significant difference with Group S and $\mathrm{E}(P<0.05)$ while there was no significant difference between Group $\mathrm{S}$ and $\mathrm{E}$. Correlation between implant angulation and RMS value was significant in Group E $(P<0.05)$. Conclusion: The pick-up impression coping method showed higher accuracy and there was no significant difference in accuracy between the healing abutment and the scan body. The clinical use of the encoded healing abutment is possible, but it should be used with caution in the case of angulated implant. (J Dent Rehabil Appl Sci 2020;36(1):29-40)

Key words: Intraoral impression technique; encoded healing abutment; implant impression; comparison accuracy; 3D deviation

\section{Introduction}

There are many clinical and laboratory steps in the manufacture of implant prosthesis. ${ }^{1}$ To obtain the accurate fit of the prosthesis, the errors in each step should be minimized. ${ }^{2}$ Therefore, inaccurate oral records may reduce the accuracy of the prosthesis, which may lead to failure of treatment. ${ }^{3}$

The accuracy of definitive cast for the manufacture of implant prosthesis is affected by several factors such as impression method, impression material, type of stone material, and pouring technique. ${ }^{3-5}$ Inaccurate impressions can lead to inadequate restorations and biologic or mechanical complications, so clini-

${ }^{*}$ Correspondence to: Joon-Seok Lee

Professor, Department of Prosthodontics, College of Dentistry, Dankook University, 119 Dandae-ro, Dongnam-gu, Cheonan, 31116, Republic of Korea

Tel: +82-41-550-0256, Fax: +82-41-550-1865, E-mail: joon322@dankook.ac.kr

Received: February 21, 2020/Last Revision: March 4, 2020/Accepted: March 7 ,

2020 cians should always strive to achieve good fit.

The method of implant impression is traditionally divided to the open-tray method using pick-up impression coping and the closed-tray method using transfer impression coping. Much research has been done comparing the accuracy of the two impression methods. Although there is no significant difference in the number of implants below 3, the open-tray method is more accurate in most studies with more than 4 implants. ${ }^{3,6-9}$ And implant placement angle may affect the accuracy of the impression. ${ }^{10}$

Traditional impression taking and model fabrication process may cause errors due to shrinkage, uneven thickness, separation, distortion, and swelling. ${ }^{11}$

Copyright@ 2020 The Korean Academy of Stomatognathic Function and Occlusion (c) It is identical to Creative Commons Non-Commercial License. 
Recent years, digital intraoral impression method has been introduced with advances in dental CAD/CAM systems, and it is possible to reduce the error that may occur during the laboratory process by a simple manufacturing process. ${ }^{12,13}$

The digital impression taking of implant requires a transfer post, mainly a scan body is used for it. ${ }^{14}$ However, both the traditional impression and the digital impression method using a scan body require removal of the healing abutment, and it has been reported that there is a possibility of damage to the soft tissue around the implant when removing or reconnect the healing abutment. ${ }^{15}$ Therefore, reducing the frequency of healing abutment removal will help maintain health of surrounding soft tissue and minimize the patient's discomfort.

To simplify implant impression techniques, a new implant restorative system using CAD/CAM technology was introduced called Encode restorative system. There is a digital identification code on the encoded healing abutment which informs the location of the implant, so that it is possible to make a digital impression directly without removing the healing abutment. ${ }^{16-18}$ This can prevent mucosal injury that may occur when the abutment is removed or reconnect, and can reduce patient discomfort, impression time and cost. ${ }^{19}$

There are not many studies about encoded healing abutment, and a study has shown that the shorter diameter and length of the scan body, the higher the error rate. ${ }^{20}$ Therefore, it is necessary to study the accuracy of the impression method using the encoded healing abutment. In this study, the purpose was to compare the accuracy of three different implant placement angles with the encoded healing abutment, scan body, and pick-up impression coping impression method.

\section{Materials and Methods}

\section{Fabrication of master model}

$40 \mathrm{~mm}$ long edentulous ridge block was designed with 3D modeling software (Autodesk 123D design, Autodesk Inc., San Rafael, USA). A cylindrical recipient spaces of $\varnothing 4.5 \times 10.0 \mathrm{~mm}$ were formed for placement of the implant analog at the first premolar (PM1), second premolar (PM2), and second molar (M2) region. PM1 was formed to be parallel to tooth axis, PM2 was formed to $10^{\circ}$ mesial inclination and $\mathrm{M} 2$ to be $20^{\circ}$ mesial inclination. Then, a vertical box was formed to the distal side of the block so that it could serve as a stop when taking impression using individual tray. The design files were saved as STL files and printed out using 3D printer (Objet EDEN260V ${ }^{\circledR}$, Stratasys Ltd., Eden Prairie, USA) with acrylic printing material (Objet Verodent MED670, Stratasys Ltd.).

$\varnothing 4.3 \times 10.0 \mathrm{~mm}$ implant analogues (ISLA500, Neobiotech, Seoul, Korea) were placed into each recipient space, and fixed with resin cement (Super Bond C \& B, Sun Medical Co. Ltd., Moriyama, Japan) (Fig. 1).

The abutment to be secured into the master model was designed with $5.0 \mathrm{~mm}$ diameter, $3.0 \mathrm{~mm}$ cuff and $5.0 \mathrm{~mm}$ height using CAD software (Dental system $^{\text {TM }}$, 3shape, Copenhagen, Denmark). The abutment was milled using a CAM machine (Plus Mill BX4, Dental Plus, Seoul, Korea) and then, abutment was sandblasted to improve the accuracy of scanning. Fig. 2 shows the abutment image on CAD.

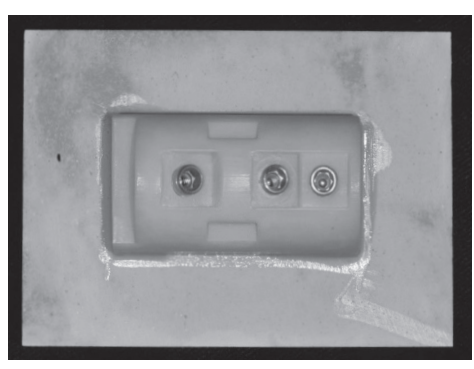

Fig. 1. Master model with analogues inserted.

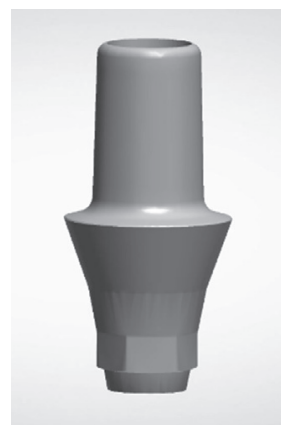

Fig. 2. Digital file of experimental abutment. 


\section{Fabrication of reference model}

The abutment was tightened with $15 \mathrm{Ncm}$ to the implant of master model. To increase the accuracy of the scanner, a 3D scanner (Freedom HD, DOF Inc., Seoul, Korea) was used after applying scan powder (EASY SCAN, ALPHADENT Co. Ltd., Goyang, Korea). Then the reference model data was saved to STL file.

\section{Fabrication of the test models}

The classification of test group according to impression method is as follows. Fig. 3 shows copings that used to make impression at each group.

Group P : Pick-up impression coping (open-tray) 15 files

Group S : Scan body digital impression - 15 files

Group E: Encoded healing abutment digital impression - 15 files

\section{Pick-up impression model}

The individual trays were made with two base plate waxes to provide uniform thickness of impression material. The open-tray type individual tray was made with tray resin (Quicky, NISSIN Dental products Inc., Kyoto, Japan) so as to have a stop on the stop part of the master model and the reference box. The pick-up impression copings ( $\varnothing 4.5$, ISIPS411, Neobiotech) were tightened into implant with a constant

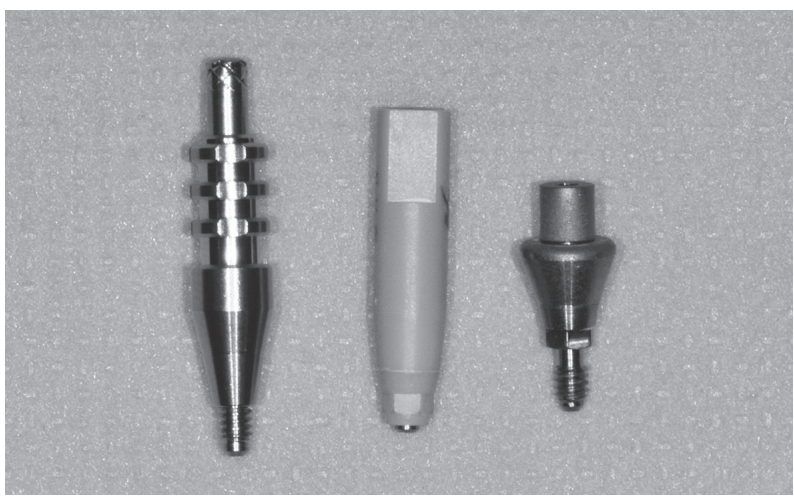

Fig. 3. Pick-up impression coping, scanbody and encoded healing abutment used in each group $\mathrm{P}, \mathrm{S}$ and $\mathrm{E}$. torque of $15 \mathrm{Ncm}$ and then impression was taken with polyvinyl siloxane (PVS) impression material (Honigum, DMG, Hamburg, Germany). After impression material was set and removed form master model, the implant analogues were secured with 5 $\mathrm{Ncm}$ to the pick-up impression copings in the individual tray. This process was repeated 15 times and a new pick-up impression coping and individual tray were used. Models were fabricated with the type IV dental stone (Fuji rock EP, GC Corp., Tokyo, Japan), and carefully trimmed to minimize discrepancies from the master model.

After the stone models by pick-up impression taking were completed, the abutments ( $\varnothing$ 5.0, cuff 3.0, height $5.0 \mathrm{~mm}$ ) were secured to the implants with 15 Ncm. Then, the 3D scanner (Freedom HD, DOF Inc.) was used for scanning and save as STL file.

\section{Scan body impression model}

The $\varnothing 4.0$ scan body (ISPSBH40NB, Neobiotech) was tightened with torque of $15 \mathrm{Ncm}$ on the implant of the master model, and a digital impression was made 15 times using intraoral scanner (TRIOS, 3Shape). Acquired impression files were imported into the CAD software (Dental system ${ }^{\mathrm{TM}}$, 3shape) and the position of the implants were obtained by superimposing the library data provided by the manufacturer of the scan body. Then, digital abutments were placed in each implant position and the 3D image data was converted using CAD software (Exocad $^{\circledR}$, Exocad GmbH, Darmstadt, Germany) and save as STL files.

\section{Encoded healing abutment impression model}

The $\varnothing 5.3$ encoded healing abutment (ISEHA503S, Neobiotech) were tightened with $15 \mathrm{Ncm}$ torque to each implants of the master model. To increase the accuracy of the impression, a scan powder was applied and impression was made 15 times using an intraoral scanner (Fig. 4). Acquired impression files were imported into the CAD software and the positions of the implants were obtained by superimposing the library data provided by the manufacturer 


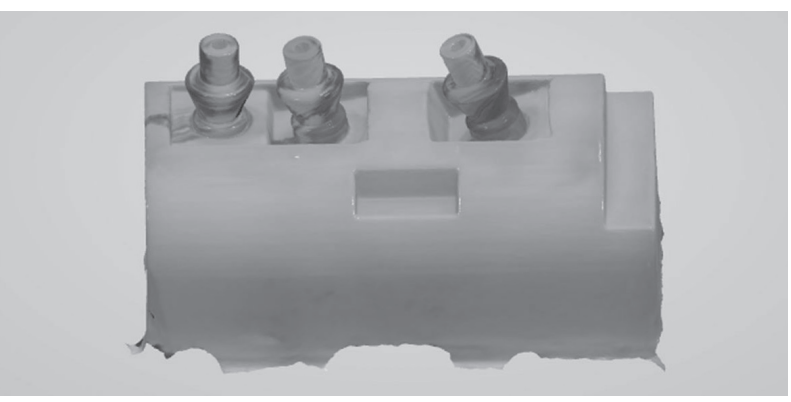

Fig. 4. Scan data of Group E.

of the scan body. After that, 3D images data was converted to a STL file in the same way as scan body impression.

\section{Data analysis}

Each STL file was imported into 3D analysis software (Geomagic ${ }^{\circledR}$ Control X, 3D systems Inc., USA) and the unnecessary parts were removed for accurate overlap. Then, the reference model was set as the reference object, each test group model was set as the measurement object, and the overlapping was performed using the best fit alignment which is the most frequently used overlapping method for accuracy analysis. ${ }^{21}$ The color coded map was used for the analysis of three dimensional error and the accept-

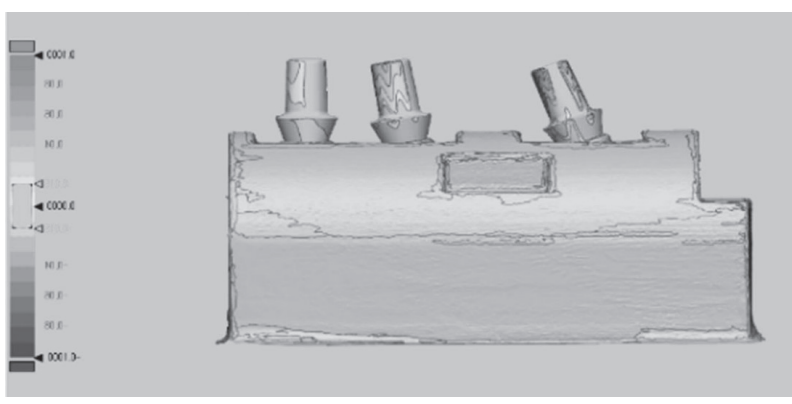

Fig. 5. 3D comparison between reference model and test models illustrated in color-coded map of all abutments.

able error was set to $15 \mu \mathrm{m}$ and the maximum error range was set to $\pm 100 \mu \mathrm{m}$.

The root mean square (RMS) value was calculated to compare the discrepancies between reference and experimental abutments. In order to find the difference according to the impression method, RMS values were measured in three abutments in group P, S and $\mathrm{E}$ (Fig. 5), and each group was divided into three subgroups (Table 1). The RMS values were compared in the abutments of PM1 $\left(0^{\circ}\right)$ for subgroup a0, PM2 $\left(10^{\circ}\right)$ for subgroup a1, and M2 (20 ) for subgroup a2.

\section{Statistical analysis}

The mean and standard deviation of RMS values were measured for each group and statistical analysis

Table 1. Classification of all groups in this study

\begin{tabular}{|c|c|c|c|c|}
\hline Method & Group & Sub-group & Compared parts & No. of data \\
\hline \multirow[t]{4}{*}{ Pick-up impression coping } & Group P & & All abutments & 15 \\
\hline & & $\mathrm{Pa} 0$ & $\operatorname{PM} 1\left(0^{\circ}\right)$ & 15 \\
\hline & & Pa1 & PM2 $\left(10^{\circ}\right)$ & 15 \\
\hline & & $\mathrm{Pa} 2$ & $\operatorname{M} 2\left(20^{\circ}\right)$ & 15 \\
\hline \multirow[t]{4}{*}{ Scan body } & Group S & & All abutments & 15 \\
\hline & & $\mathrm{Sa} 0$ & $\operatorname{PM} 1\left(0^{\circ}\right)$ & 15 \\
\hline & & Sa1 & PM2 $\left(10^{\circ}\right)$ & 15 \\
\hline & & $\mathrm{Sa} 2$ & $\operatorname{M} 2\left(20^{\circ}\right)$ & 15 \\
\hline \multirow[t]{4}{*}{ Encoded healing abutment } & Group E & & All abutments & 15 \\
\hline & & $\mathrm{Ea} 0$ & PM1 $\left(0^{\circ}\right)$ & 15 \\
\hline & & Ea1 & PM2 $\left(10^{\circ}\right)$ & 15 \\
\hline & & $\mathrm{Ea} 2$ & $\mathrm{M} 2\left(20^{\circ}\right)$ & 15 \\
\hline
\end{tabular}


was performed using SPSS v23.0 (IBM SPSS Inc., Chicago, USA). Kolmogorov-Smirnov analysis and Shapiro-Wilk analysis were performed for the regularity test. One-way ANOVA test was performed and the Dunnett T3 test was performed for post-analysis. The Jonckheere-Terpstra test was used to examine the correlation between the angulation of the implant and the error $(P=0.05)$.

\section{Results}

Table 2 shows the mean and standard deviation of RMS values for each group. The RMS values were highest in group $\mathrm{E}(38.29 \pm 4.12 \mu \mathrm{m})$, followed by group $\mathrm{S}(35.27 \pm 2.56 \mu \mathrm{m})$ and group $\mathrm{P}(25.56 \pm 2.53$ $\mu \mathrm{m})$. And Fig. 6 shows a typical features of color coded map in each group. In the color coded map, green color means that the experimental model is

Table 2. Mean and standard deviation of RMS values for all test groups (Unit: $\mu \mathrm{m}$ )

\begin{tabular}{cccc}
\hline Group & Sub-group & Mean & SD \\
\hline $\mathrm{P}$ & & 25.56 & 2.53 \\
$\mathrm{~S}$ & & 35.27 & 2.56 \\
$\mathrm{E}$ & & 38.29 & 4.12 \\
& $\mathrm{~Pa} 0$ & 21.15 & 5.58 \\
& $\mathrm{~Pa} 1$ & 24.98 & 5.19 \\
& $\mathrm{~Pa} 2$ & 25.65 & 8.09 \\
& $\mathrm{Sa} 0$ & 34.56 & 4.80 \\
& $\mathrm{Sa} 1$ & 33.68 & 4.05 \\
& $\mathrm{Sa} 2$ & 37.17 & 2.91 \\
& $\mathrm{Ea} 0$ & 33.83 & 2.88 \\
& $\mathrm{Ea} 1$ & 39.69 & 4.31 \\
& $\mathrm{Ea} 2$ & 37.62 & 4.69 \\
\hline
\end{tabular}

within $15 \mu \mathrm{m}$ of the reference model, red color is positive, which is outside the reference model, and blue color is negative, which is inside the reference model.

The normality test of the RMS values revealed normal distribution in all the groups and all subgroups. One-way ANOVA test was performed to find out the difference between impression methods, and result of the test showed statistically significant $(P<0.05$, Table 3, 4), therefore Dunnett T3 test was performed for post-hoc analysis. As a result, the RMS values of the group $\mathrm{P}$ were smaller than those of the group $\mathrm{E}$ and $\mathrm{S}(P<0.05)$, and there was no significant difference between the group $\mathrm{E}$ and the group S (Table 5).

To determine whether the implant placement angle affects accuracy of impression, one-way ANOVA and Dunnett T3 test were performed on the subgroups. RMS values of $\mathrm{a} 0$ and $\mathrm{a} 2$ in group $\mathrm{P}$ were significantly smaller than those of group $\mathrm{S}$ and $\mathrm{E}$ $(P<0.05)$, and there was no significant difference in RMS values between $\mathrm{a} 0$ and $\mathrm{a} 2$ of group $\mathrm{S}$ and E (Table 6, 8). RMS values of a1 were the lowest in group $\mathrm{P}$, and significantly higher in group $\mathrm{S}$ and group $\mathrm{E}(P<0.05$, Table 7$)$.

The result of Jonckheere-Terpstra test for the correlation of the RMS values according to the angulation of the implant showed a correlation in group $\mathrm{E}$ $(P<0.05)$, which RMS value was $33.83 \pm 2.88 \mu \mathrm{m}$ $(\mathrm{Ea} 0), 39.69 \pm 4.31 \mu \mathrm{m}(\mathrm{Ea} 1)$ and $37.62 \pm 4.69 \mu \mathrm{m}$ (Ea2). No significant correlation was shown in group $\mathrm{P}$ and group S (Table 9).
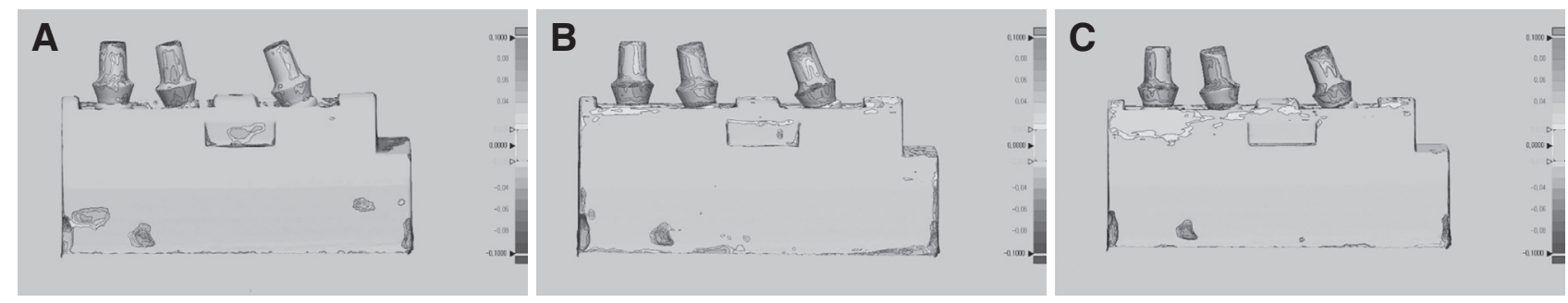

Fig. 6. Color coded map of 3D comparison between reference model and (A) Group P, (B) Group S, (C. Group E. 
Table 3. Results of one-way ANOVA for RMS values between Group P, S and E

\begin{tabular}{llccccc}
\hline & & Sum of Squares & df & Mean Square & F & $P$ \\
\hline \multirow{3}{*}{ Group P, S, E } & Between Groups & .001 & .001 & .001 & 39.600 & $.001 *$ \\
& Within Groups & .001 & 42 & .000 & & \\
& Total & .002 & 44 & & & \\
\hline
\end{tabular}

* Statistical significance $P<0.05$.

Table 4. Results of one-way ANOVA for RMS values in subgroups

\begin{tabular}{|c|c|c|c|c|c|c|}
\hline & & Sum of Squares & $\mathrm{df}$ & Mean Square & $\mathrm{F}$ & $P$ \\
\hline Sub-group a0 & Between Groups & .002 & 2 & .001 & 38.239 & $.001 *$ \\
\hline \multirow[t]{2}{*}{$(\mathrm{Pa} 0, \mathrm{Sa} 0, \mathrm{Ea} 0)$} & Within Groups & .001 & 42 & .001 & & \\
\hline & Total & .003 & 44 & & & \\
\hline Sub-group a1 & Between Groups & .002 & 2 & .001 & 37.034 & $.001 *$ \\
\hline \multirow[t]{2}{*}{ (Pa1, Sa1, Ea1) } & Within Groups & .001 & 42 & .001 & & \\
\hline & Total & .003 & 44 & & & \\
\hline Sub-group a2 & Between Groups & .001 & 2 & .001 & 20.104 & $.001 *$ \\
\hline \multirow[t]{2}{*}{ (Pa2, Sa2, Ea2) } & Within Groups & .001 & 42 & .001 & & \\
\hline & Total & .003 & 44 & & & \\
\hline
\end{tabular}

* Statistical significance $P<0.05$.

Table 5. Results of post hoc Dunnet T3 test of RMS value for Group P, S and E (Unit: $\mu \mathrm{m})$

\begin{tabular}{lccc}
\hline$P$ & Group P $(25.56 \pm 2.53)$ & Group S $(35.27 \pm 2.56)$ & Group E (38.29 \pm 4.12$)$ \\
\hline Group P & $.001^{*}$ & \\
Group S & $.001^{*}$ & .119 \\
Group E & & & \\
\hline
\end{tabular}

* Statistical significance $P<0.05$.

Table 6. Results of post hoc Dunnet T3 test of RMS value for sub-group a0 (Unit: $\mu \mathrm{m}$ )

\begin{tabular}{llccc}
\hline & $P$ & Group Pa0 & Group Sa0 & Group Ea0 \\
Sub-group a0 & Group Pa0 & $(21.15 \pm 5.58)$ & $(34.56 \pm 4.80)$ & $(33.83 \pm 2.88)$ \\
\cline { 2 - 5 } & Group Sa0 & $.001^{*}$ & .946 \\
\hline
\end{tabular}

* Statistical significance $P<0.05$.

Table 7. Results of post hoc Dunnet T3 test of RMS value for sub-group a1 (Unit: $\mu \mathrm{m}$ )

\begin{tabular}{llccc}
\hline & $P$ & Group Pa1 & Group Sa1 & Group Ea1 \\
Sub-group a1 & Group Pa1 & $(24.98 \pm 5.19)$ & $(33.68 \pm 4.05)$ & $(39.69 \pm 4.31)$ \\
\cline { 2 - 4 } & Group Sa1 & $.001 *$ & \\
& Group Ea1 & $.001 *$ & $.002^{*}$ & \\
\hline
\end{tabular}

* Statistical significance $P<0.05$. 
Table 8. Results of post hoc Dunnet T3 test of RMS value for sub-group a2 (Unit: $\mu \mathrm{m}$ )

\begin{tabular}{llccc}
\hline & $P$ & Group Pa2 & Group Sa2 & Group Ea2 \\
Sub-group a2 & Group Pa2 & $(25.65 \pm 8.09)$ & $(37.17 \pm 2.91)$ & $(37.62 \pm 4.69)$ \\
\cline { 2 - 5 } & Group Sa2 & $.001 *$ & \\
& Group Ea2 & $.001 *$ & .986 \\
\hline
\end{tabular}

* Statistical significance $P<0.05$.

Table 9. Results of Jonckheere-Terpstra test of RMS value for Group P, S and E

\begin{tabular}{lccc}
\hline & Group P & Group S & Group E \\
\hline Number of Levels in Angle & 3 & 3 & 3 \\
N & 45 & 45 & 45 \\
Observed J-T Statistic & 420.0 & 425.0 & 433.0 \\
Mean J-T Statistic & 227.5 & 337.5 & 337.5 \\
Std. Deviation of J-T Statistic & 48.022 & 48.011 & 48.006 \\
Std. J-T Statistic & 1.718 & 1.822 & 1.989 \\
Asymp. Sig. (2-tailed) & .086 & 0.068 & $.047^{*}$ \\
\hline
\end{tabular}

* Statistical significance $P<0.05$.

\section{Discussion}

The purpose of this study is to compare the accuracy of the impression method using the encoded healing abutment with the traditional open-tray method and the conventional digital impression scan body method and to determine whether the angulation of implant affects the accuracy of the impression. In 2006, Grossmann et al. ${ }^{16}$ introduced an impression method using an encoded healing abutment, but there are not many studies about the accuracy of this method. ${ }^{22-25}$ In addition, they mainly analyzed the linear deformation or angular deformation using the center point of the implant platform or the upper spherical structure, which may have limitations in confirming the error that may occur when fabricating the prosthesis in clinic, and other errors may be generated accordingly since the coordinates are manually determined. $^{22-24}$

In this study to compare the accuracy with situation simulating more clinical, the abutment was designed and milled with CAD/CAM system and
RMS of three-dimensional error value of the abutment part was measured and compared. As a result, the differences of accuracy were found according to the impression methods and the null hypothesis that there is no significant difference according to the impression was rejected. The impression method using the encoded healing abutment showed a higher RMS value than the pick-up impression coping method $(P$ $<0.05)$ regardless of the angle of implant and conventional pick-up impression coping method showed the highest accuracy. Other previous studies reported the encoded impression group showed larger error than the pick-up impression group, and in this study the error of encoded healing group was $33-50 \mu \mathrm{m}$ and that of pick-up impression group was $18-32 \mu \mathrm{m}$. Eliasson and Ortorp showed differences of $79.5 \mu \mathrm{m}$ and $31.2 \mu \mathrm{m}$, Simon et al. showed $65-107 \mu \mathrm{m}$ and $13-20 \mu \mathrm{m}$, Howell et al. showed 35 - $242 \mu \mathrm{m}, 2.4$ $161.9 \mu \mathrm{m}$, and Abdullah et al. showed 48 - $228 \mu \mathrm{m}$ and $14-25 \mu \mathrm{m}$ in the difference of encoded impression and pick-up impression, respectively. ${ }^{22-25}$ The error values of this study showed similar to those of 
Eliasson and Ortorp and Simon et al. On the other hand, the results of the study by Howell et al. and Abdullah et al. showed a larger error than those of this study since they measured at the position of the occlusal plane. ${ }^{22-25}$ This study is conducted in threedimensional and more similar to the clinical situation.

In group $\mathrm{E}$, there was a positive correlation between the implant angulation and error. Encoded healing abutments are more likely to show inaccuracies with inclinations because of their smaller impression surface. Although previous studies reported that increase in angulation did not increase the error in the encoded healing group, ${ }^{23,25}$ another study reported the encoded healing abutments at $15^{\circ}$ angulation showed larger error than $0^{\circ}$ implant. ${ }^{24}$ And there is a possibility that the collar portion of the encoded healing abutment may be embedded in the gingiva due to the tilt of the implant. ${ }^{25}$ Therefore, it is considered that collar area should be located at least 1 $\mathrm{mm}$ above the gingiva during impression when using an encoded healing abutment in inclined implant. In this study, group $\mathrm{S}$ and $\mathrm{P}$ were not correlated with the error according to the implant angulation (Table 7), and similar results were obtained in other recent studies. ${ }^{26-28}$ Moura et al. compared accuracy of traditional impression method and scan body method with a $15^{\circ}$ implant angulation and there was no significant difference. ${ }^{26}$ However, Assunaco et al. reported that the error was increased with the inclination of the implant, and a larger error was shown with the angulation of $25^{\circ}$ implant. ${ }^{11,29}$ Therefore, according to the results of present study, it is difficult to conclude that the pick-up impression method and the scan body impression method are free of implant angulation, and further studies on the implants with larger angulation seem to be needed.

The 'best fit algorithm' is a method currently used to superimpose the STL datasets and analyze the accuracy. $^{21}$ As a result of the best fit alignment between the reference model and the test model, positive or negative values are produced, which is difficult to represent the actual deviation value by canceling each other. These inaccuracies could be avoided by using root-mean-square (RMS) calculations to analyze 3D deviations. ${ }^{30}$ Previous studies used 'least squares method' or 'zero method' at best alignment and set scan body as the overlap reference. ${ }^{31-33}$ However, it might be difficult to measure the actual deviation value with the scan body which is the target of the alignment. In color coded map of this study, most areas in group $\mathrm{P}$ were green color range which means less error, and red or blue color were more observed in the group $\mathrm{S}$ and $\mathrm{E}$. In group $\mathrm{S}$ and $\mathrm{E}$, blue color was observed in the mesial lower part of the abutment and red color was observed in the distal upper part of the abutment at PM2 or M2, which could be interpreted as impression model is less inclined than the master model. Additional attention should be paid to the impression of an inclined implant when using an intraoral scanner.

Although a highly reproducible coordinate measuring machine (CMM) can be used for accuracy analysis $(2 \mu \mathrm{m})$, results of CMM are generated as solid data and the data loss occurs causing additional errors during transforming into STL data for best-fit alignment. ${ }^{22,23}$ Furthermore, CMM is quite expensive, and its measurement processing time is long. Measuring a specimen with a complicated inner surface is difficult, because the CMM probe requires contact with the surface of the specimen. On the other hand, the 3D scanner used in this study has many advantages such as reproducibility of $15 \mu \mathrm{m}$, low cost and short time.

In group $\mathrm{S}$ and $\mathrm{E}$, an intraoral scanner was used. Although the intraoral scanner has a disadvantage of that larger errors may appear depending on the operator, the intraoral scanner is used in the group $\mathrm{S}$ and $\mathrm{E}$ in order to simulate the actual clinical situation. ${ }^{33}$

In the reference model and group P, milled abutment is used and error occurs during milling process $(10-20 \mu \mathrm{m}){ }^{34,35}$ Therefore it could be considered that the group $\mathrm{S}$ and group $\mathrm{E}$ have more RMS values than the group P due to the error of the milled abutment used in the reference model. In recent research, the scan body is as accurate as pick-up impression coping. $^{36}$

Recently, many clinical cases using an encoded healing abutment have been reported..$^{16,19,37-40}$ Representative advantages of an encoded healing abutment are simple impression procedure, economical and 
no need of removing the healing abutment until the final restoration. Additionally, it may be useful when the scan body or impression coping could not be screwed by the inclined adjacent tooth. In the case of an impression using the conventional scan body, the shape of the gingival form of the healing abutment and the scan body are different each other, resulting in errors and damage to the gingiva and pain. ${ }^{37,40}$ However, because the encoded healing abutment has both gingival height and diameter information, it is possible to fabricate the abutment which is same with the upper gingival shape of the implant. Therefore, the use of an encoded healing abutment is likely to increase if further studies are performed and the disadvantages are supplemented.

\section{Conclusions}

In this study, the accuracies of three types of impression methods (encoded healing abutment, scan body, pick-up coping) were compared at various implant angles and the following conclusions were drawn.

1. The pick-up impression coping method was significantly more accurate than the encoded healing abutment and scan body impression method $(P<0.05)$.

2. The accuracy of encoded healing abutment and scan body impression method was not significantly different.

3. When using the encoded healing abutment impression method, the accuracy of impression significantly decreased as the angulation of implant was increased. Scan body and pick-up impression coping method, however, did not show a statistically significant correlation.

According to the results of this study, the use of the encoded healing abutment as a scan body can be clinically used. However, it should be used with caution when implants are placed with an angle.

\section{ORCID}

Gyo-Zin Ahn https://orcid.org/0000-0001-9400-355X

Joon-Seok Lee https://orcid.org/0000-0003-2962-1380

\section{References}

1. Branemark PI, Zarb GA, Albrektsson T. Tissueintegrated prostheses: Osseointegration in clinical dentistry. Chicago; Quintessence; 1985. p. 611-12.

2. Wee AG, Aquilino SA, Schneider RL. Strategies to achieve fit in implant prosthodontics: a review of the literature. Int J Prosthodont 1999;12:167-78.

3. Del'Acqua MA, Arioli-Filho JN, Compagnoni MA, Mollo Fde A Jr. Accuracy of impression and pouring techniques for an implant-supported prosthesis. Int J Oral Maxillofac Implants 2008;23:226-36.

4. Del'Acqua MA, Chávez AM, Amaral AL, Compagnoni MA, Mollo Fde A Jr. Comparison of impression techniques and materials for an implant-supported prosthesis. Int J Oral Maxillofac Implants 2010;25:771-6.

5. Wee AG, Schneider RL, Aquilino SA, Huff TL, Lindquist TJ, Williamson DL. Evaluation of the accuracy of solid implant casts. J Prosthodont 1998;7: 161-9.

6. Cabral LM, Guedes CG. Comparative analysis of 4 impression techniques for implants. Implant Dent 2007;16:187-94.

7. Conrad HJ, Pesun IJ, DeLong R, Hodges JS. Accuracy of two impression techniques with angulated implants. J Prosthet Dent 2007;97:349-56.

8. Wenz HJ, Hertrampf K. Accuracy of impressions and casts using different implant impression techniques in a multi-implant system with an internal hex connection. Int J Oral Maxillofac Implants 2008;23:39-47.

9. Lee H, So JS, Hochstedler JL, Ercoli C. The accuracy of implant impressions: a systematic review. J Prosthet Dent 2008;100:285-91.

10. Assuncao WG, Filho HG, Zaniquelli O. Evaluation of transfer impressions for osseointegrated implants at various angulations. Implant Dent 2004; 13:358-66.

11. Christensen GJ. Will digital impressions eliminate the current problems with conventional impressions? J Am Dent Assoc 2008;139:761-3.

12. Beuer F, Schweiger J, Edelhoff D. Digital dentistry: an overview of recent developments for CAD/ CAM generated restorations. Br Dent J 2008;204: 
505-11.

13. Ender A, Mehl A. Full arch scans: conventional versus digital impressions-an in-vitro study. Int J Comput Dent 2011;14:11-21.

14. Stimmelmayr M, Güth JF, Erdelt K, Edelhoff D, Beuer F. Digital evaluation of the reproducibility of implant scanbody fit-an in vitro study. Clin Oral Investig 2012;16:851-6.

15. Abrahamsson I, Berglundh T, Lindhe J. The mucosal barrier following abutment dis/reconnection. An experimental study in dogs. J Clin Periodontol 1997;24:568-72.

16. Grossmann Y, Pasciuta M, Finger IM. A novel technique using a coded healing abutment for the fabrication of a CAD/CAM titanium abutment for an implant-supported restoration. J Prosthet Dent 2006;95:258-61.

17. Fuster-Torres MA, Albalat-Estela S, Alcañiz-Raya M, Peñarrocha-Diago M. CAD/CAM dental systems in implant dentistry: update. Med Oral Patol Oral Cir Bucal 2009;14:E141-5.

18. Kapos T, Ashy LM, Gallucci GO, Weber HP, Wismeijer D. Computer-aided design and computerassisted manufacturing in prosthetic implant dentistry. Int J Oral Maxillofac Implants 2009;24:110-7.

19. Nayyar N, Yilmaz B, McGlumphy E. Using digitally coded healing abutments and an intraoral scanner to fabricate implant-supported, cement-retained restorations. J Prosthet Dent 2013;109:210-5.

20. Fluegge T, Att W, Metzger M, Nelson K. A novel method to evaluate precision of optical implant impressions with commercial scan bodies-an experimental approach. J Prosthodont 2017;26:34-41.

21. Ting-Shu S, Jian S. Intraoral digital impression technique: a review. J Prosthodont 2015;24:313-21.

22. Eliasson A, Ortorp A. The accuracy of an implant impression technique using digitally coded healing abutments. Clin Implant Dent Relat Res 2012;14 Suppl 1:e30-8.

23. Ng SD, Tan KB, Teoh KH, Cheng AC, Nicholls JI. Three-dimensional accuracy of a digitally coded healing abutment implant impression system. Int J Oral Maxillofac Implants 2014;29:927-36.

24. Howell KJ, McGlumphy EA, Drago C, Knapik G. Comparison of the accuracy of Biomet $3 i$ Encode robocast technology and conventional implant impression techniques. Int J Oral Maxillofac Implants 2013;28:228-40.

25. Al-Abdhullah K, Zandparsa R, Finkelman M, Hirayama $H$. An in vitro comparison of the accuracy of implant impressions with coded healing abutments and different implant angulations. J Prosthet Dent 2013;110:90-100.

26. Moura RV, Kojima AN, Saraceni CHC, Bassolli L, Balducci I, Özcan M, Mesquita AMM. Evaluation of the accuracy of conventional and digital impression techniques for implant restorations. J Prosthodont 2019;28:e530-5.

27. Alexander Hazboun GB, Masri R, Romberg E, Kempler J, Driscoll CF. Effect of implant angulation and impression technique on impressions of NobelActive implants. J Prosthet Dent 2015;113: 425-31.

28. Papaspyridakos P, Gallucci GO, Chen CJ, Hanssen S, Naert I, Vandenberghe B. Digital versus conventional implant impressions for edentulous patients: accuracy outcomes. Clin Oral Implants Res 2016; 27:465-72.

29. Filho HG, Mazaro JV, Vedovatto E, Assunação WG, Dos Santos PH. Accuracy of impression techniques for implants. Part 2 - comparison of splinting techniques. J Prosthodont 2009;18:172-6.

30. Amin S, Weber HP, Finkelman M, El Rafie K, Kudara Y, Papaspyridakos P. Digital vs. conventional full-arch implant impressions: a comparative study. Clin Oral Implants Res 2017;28:1360-7.

31. Güth JF, Keul C, Stimmelmayr M, Beuer F, Edelhoff $\mathrm{D}$. Accuracy of digital models obtained by direct and indirect data capturing. Clin Oral Investig 2013;17:1201-8.

32. Jemt T. Hjalmarsson L. In vitro measurements of precision of fit of implant-supported frameworks. A comparison between "virtual" and "physical" assessments of fit using two different techniques of measurements. Clin Implant Dent Relat Res 2012; 14 Suppl 1:e175-82.

33. Giménez B, Özcan M, Martínez-Rus F, Pradíes G. Accuracy of a digital impression system based on parallel confocal laser technology for implants with consideration of operator experience and implant 
angulation and depth. Int J Oral Maxillofac Implants 2014;29:853-62.

34. Srinivasan M, Cantin Y, Mehl A, Gjengedal H, Muller F, Schimmel M. CAD/CAM milled removable complete dentures: an in vitro evaluation of trueness. Clin Oral Investig 2017;21:2007-19.

35. Kim CM, Kim SR, Kim JH, Kim HY, Kim WC. Trueness of milled prostheses according to number of ball-end mill burs. J Prosthet Dent 2016;115: 624-9.

36. Matta RE, Adler W, Wichmann M, Heckmann SM. Accuracy of impression scanning compared with stone casts of implant impressions. J Prosthet Dent 2017;117:507-12.

37. Abduo J, Chen C, Le Breton E, Radu A, Szeto J, Judge R, Darby I. The effect of coded healing abutments on treatment duration and clinical outcome: a randomized controlled clinical trial comparing encode and conventional impression protocols. Int J Oral Maxillofac Implants 2017;32:1172-9.

38. Mahn DH, Prestipino T. CAD/CAM implant abutments using coded healing abutments: a detailed description of the restorative process. Compend Contin Educ Dent 2013;34:612-5.

39. Telleman G, Raghoebar GM, Vissink A, Meijer HJ. The use of a coded healing abutment as an impression coping to design and mill an individualized anatomic abutment: a clinical report. J Prosthet Dent 2011;105:282-5.

40. Dhima M. Correction of bone and softtissue deformity of the single implant in the aesthetic zone: a case treated with alveolar ridge preservation, modified roll technique and a digitally coded healing abutment. Eur J Prosthodont Restor Dent 2014;22:51-5. 


\section{임플란트 디지털 인상용 코핑의 정확성 비교}

\section{안교진 전문의, 이준석* 교수}

단국대학교 치과대학 치과보철학교실

목적: Encoded healing abutment와 scan body를 이용한 디지털 인상과 pick-up 인상용 코핑을 이용한 인상 채득법의 정 확도를 다른 임플란트 식립 각도에서 비교 연구하고자 하였다.

연구 재료 및 방법: $3 \mathrm{D}$ 프린터를 이용해 주모형을 제작하고 $0^{\circ}, 10^{\circ}$ 및 $20^{\circ}$ 의 근심경사로 3 개의 임플란트를 위치 시켰다. 각각의 임플란트에 지대주를 체결하고 주모형을 스캔하여 참조 모델을 만들었다. P군 모델은 pick-up 인상용 코핑을 사 용하여 15 개의 석고 모형을 만들고 지대주를 장착 후 스캔하여 제작하였다. $\mathrm{E}$ 군과 $\mathrm{S}$ 군의 모델은 각각 encoded healing abutment와 scan body를 주모형에 체결하고 구내 스캐너를 이용해 15 회씩 인상채득을 하여 제작하였다. 각각의 실험군 STL 파일은 best fit alignment를 이용해 참조 모델과 중첩하였고 root mean square (RMS) 값을 분석하였다.

결과: RMS 값은 P군에서 가장 작았고 $(25.56 \pm 2.53 \mu \mathrm{m})$, 그다음 S군(35.27 $\pm 2.56 \mu \mathrm{m}), \mathrm{E}$ 군 $(38.29 \pm 4.12 \mu \mathrm{m})$ 순 이었 다. $\mathrm{S}$ 군과 $\mathrm{E}$ 군 사이에는 유의차가 없었고, $\mathrm{P}$ 군은 $\mathrm{S}$ 군과 $\mathrm{E}$ 군 보다 작았다 $(P<0.05)$. 임플란트 각도와 RMS 값의 상관관 계는 $\mathrm{E}$ 군에서 유의하였다 $(P<0.05)$.

결론:Pick-up 인상용 코핑 방법은 encoded healing abutment와 scan body 인상 채득 방법에 비해 더 높은 정확도를 보였 고 encoded healing abutment와 scan body 인상 방법은 정확도에서 유의한 차이가 없었다. Encoded healing abutment 의 임상적 사용은 가능하나 경사진 임플란트의 인상의 경우 주의하여 사용해야 할 것으로 사료된다.

(구강회복응용과학지 2020;36(1):29-40)

주요어: 구내 디지털 인상법; encoded healing abutment; 임플란트 인상; 정확도 비교; 3 차원적 분석

*교신저자: 이준석

(31116) 충청남도 천안시 동남구 단대로 119 단국대학교 치과대학 보철학교실

Tel: 041-550-0256 | Fax: 041-550-1865 | E-mail: joon322@dankook.ac. kr

접수일: 2020년 2월 21일 | 수정일: 2020년 3월 4일 | 채택일: 2020년 3월 7일 